\title{
Application of front-face fluorescence spectroscopy as a tool for monitoring changes in milk protein concentrate powders during storage
}

\author{
K. S. Babu and J. K. Amamcharla ${ }^{1}$ \\ Department of Animal Sciences and Industry/Food Science Institute, Kansas State University, Manhattan 66506
}

\begin{abstract}
This study investigated the feasibility of front-face fluorescence spectroscopy (FFFS) to predict the solubility index and relative dissolution index (RDI) of milk protein concentrate (MPC) powders during storage. Twenty MPC powders with varying protein contents from 4 different commercial manufacturers were used in this study. The MPC powders were stored at 2 temperatures $\left(25\right.$ and $\left.40^{\circ} \mathrm{C}\right)$ for $0,1,2,4,8$, and 12 wk. The front-face fluorescence spectra of tryptophan and Maillard products were recorded and analyzed with chemometrics to predict solubility of MPC powders. The similarity maps showed clear discrimination of the MPC samples stored at 25 and $40^{\circ} \mathrm{C}$. Partial least squares regression models were developed using the fluorescence spectra of tryptophan and Maillard products to predict the solubility index and RDI measurements of MPC powders, and the prediction models were validated using an independent test set. Coefficients of determination $\left(\mathrm{R}^{2}\right)$ of $0.76,0.84$, and 0.68 were obtained between fluorescence spectra (tryptophan emission, Maillard emission, and Maillard excitation, respectively) and solubility index. The $\mathrm{R}^{2}$ values for the RDI predictions were 0.58 and 0.60 for the data set of tryptophan emission and Maillard emission, respectively. The ratio of prediction error to standard deviation was $>2$ for Maillard emission fluorescence spectra and solubility index measurements, indicating good practical utility of the partial least squares regression prediction models. The results indicated that the solubility and dissolution behavior of MPC powders were related to their protein content and storage conditions that could be measured using FFFS. Hence, FFFS can be used as a rapid nondestructive analytical technique to predict the solubility and dissolution characteristics of MPC powders.
\end{abstract}

Key words: high-protein dairy powder, storage, focused beam reflectance measurement, dissolution

Received April 6, 2018.

Accepted August 28, 2018.

${ }^{1}$ Corresponding author: Jayendra@ksu.edu

\section{INTRODUCTION}

Milk protein concentrate (MPC) powders are high in protein and low in lactose content and are added as ingredients in food product formulations to enhance the nutritional, functional, and sensory properties (Agarwal et al., 2015). The consistent and proper solubility of MPC powders is critical in delivering the desired physical and functional characteristics in the finished products. Processing conditions, powder composition, storage conditions, and dissolution conditions affect the overall solubility of MPC powders (Hauser and Amamcharla, 2016a; Babu et al., 2018). Thermal processing steps can result in structural alterations in proteins due to denaturation, aggregation of whey proteins, and formation of protein complexes between whey protein and caseins (Corredig and Dalgleish, 1999; Fang et al., 2012). Subsequent storage conditions further affect the protein interactions, leading to a reduction in solubility of the MPC powders (Anema et al., 2006). Mimouni et al. (2010) observed that poor dispersible casein fractions are responsible for the high rehydration time in the MPC powders ( $>80 \%$ protein content) and slow rehydration is intensified during prolonged storage at elevated temperature and relative humidity (Crowley et al., 2015). According to Richard et al. (2012), the poor rehydration behavior of casein-dominant powders is due to slow penetration of water into primary particles. Therefore, MPC powders have the best possible solubility immediately after production, and the solubility reduces as the storage time and temperature increases (Augustin et al., 2012; Fang et al., 2012; Gazi and Huppertz, 2015).

Application of rapid spectroscopic methods in dairy food analysis can alleviate critical problems in the production, storage, and distribution of dairy products (Karoui et al., 2003). Recently, Shaikh and O'Donnell (2017) reviewed the potential of the fluorescence spectroscopy as a rapid, nondestructive tool for evaluating the quality and safety attributes of dairy products. The traditional analytical methods in food analysis are timeconsuming, relatively expensive, and labor-intensive, and these methods have limited applications for on- 
line/in-line monitoring (Karoui et al., 2003). Therefore, traditional methods alone are not adequate to meet the growing demands of the dairy industry. Thus, several nondestructive techniques have been developed to rapidly determine product quality parameters. These new rapid techniques are relatively low cost and can be applied in both fundamental research and in the dairy industry, and also as on-line sensors for monitoring dairy food production (Kamal and Karoui, 2015).

During the last 2 decades, fluorescence spectroscopy has provided essential insights into the chemical, physical, and sensory properties of several complex food products (Karoui and Blecker, 2011). Front-face fluorescence spectroscopy (FFFS) is a rapid nondestructive method, comparatively inexpensive, and provides an extensive amount of information when coupled with multivariate statistical analysis. Coupling FFFS with chemometrics is a sensitive, reliable technique that provides unique information on the presence of fluorophores and has great potential to monitor and predict physical, chemical, and functional properties of dairy products (Shaikh and O'Donnell, 2017; Granato et al., 2018).

Dairy products have several intrinsic fluorophores such as tryptophan, fluorescent Maillard reaction products, vitamin A, and NADH, which could be used as compounds of interest and are widely studied using fluorescence spectroscopy (Andersen and Mortensen, 2008). Front-face fluorescence spectroscopy coupled with chemometric tools have previously been used to characterize dairy products (Dufour and Riaublanc, 1997), monitor the structural changes and physicochemical modification during milk heat treatment and coagulation of milk proteins (Kulmyrzaev et al., 2005; Boubellouta and Dufour, 2008; Blecker et al., 2012), determine the quality of various cheeses during ripening (Karoui et al., 2007), confirm geographic origin of cheeses (Karoui et al., 2005), and monitor storage changes of nonfat dry milk (NFDM; Liu and Metzger, 2007). The objective of this study was to determine if FFFS coupled with chemometrics could be used as a rapid and nondestructive technique to monitor and predict the effect of protein content and storage time/ temperature on the solubility of MPC powders.

\section{MATERIALS AND METHODS}

\section{Milk Protein Concentrate Samples}

Milk protein concentrate powders $(\mathrm{n}=20)$ with 4 different protein contents $(70,80,85$, and $90 \%$ ) were collected from 4 different commercial manufacturers. For simplicity, the powders will be called MPC70, MPC80, MPC85, and MPC90, respectively, indicat- ing the protein content in the powders on a dry basis. To generate the MPC powders with different dissolution characteristics, each powder samples were divided into 10 equal parts $(1 \mathrm{bag}$ each for 5 storage times at 2 temperatures), individually sealed in Whirl-Pak bags (Nasco, CA) and were stored at 2 different temperatures $\left(25\right.$ and $\left.40^{\circ} \mathrm{C}\right)$ in an incubator (Percival Scientific, Perry, IA) for $0,1,2,4,8$, and 12 wk. The powders were analyzed on 0 (control), 1, 2, 4, 8, and 12 wk of storage for color, solubility, dissolution behavior, and FFFS. The strategy of storing the MPC powders $(\mathrm{n}=$ 20 ) at 2 different temperatures for 12 wk resulted in a total of 220 samples $(n=220)$ with different dissolution characteristics.

\section{Color}

On each experimental day, the color of MPC powders was determined by Hunter-Lab Mini Scan XE colorimeter (Reston, VA) to assess the changes in color caused by the Maillard reaction during the storage period. The Hunter color values were expressed as $\mathrm{L}^{*}$ (whiteness or brightness/darkness), $a^{*}$ (redness/greenness), and $b^{*}$ (yellowness/blueness). Color measurement was carried out in triplicate and reported as the mean.

\section{Solubility Index}

Milk protein concentrate solutions of $5 \%$ (wt/wt) concentration were prepared at a dissolution temperature of $40^{\circ} \mathrm{C}$ (Hauser and Amamcharla, 2016b) using distilled water, and the solubility index of the MPC powders stored at 25 and $40^{\circ} \mathrm{C}$ for $0,1,2,4,8$, and 12 wk was measured based on the TS in the supernatant obtained by centrifugation $\left(700 \times g\right.$ for $10 \mathrm{~min}$ at $\left.25^{\circ} \mathrm{C}\right)$. The pre-weighed supernatant was dried overnight in an oven at $105^{\circ} \mathrm{C}$, and the final dry material weight was recorded (Anema et al., 2006). The amount of soluble material $(\sigma)$ in the MPC powders was calculated using Equation [1].

$$
\sigma=\frac{\text { weight of dry material }}{\text { weight of solution }} \times 100 \text {. }
$$

\section{Relative Dissolution Index}

The dissolution characteristics of the MPC powders stored at $25^{\circ} \mathrm{C}$ and $40^{\circ} \mathrm{C}$ for $0,1,2,4,8$, and 12 wk were evaluated using focused beam reflectance measurement (FBRM) following the method described by Hauser and Amamcharla (2016b). Protein solutions of 5\% (wt/ wt) concentration of MPC powders were prepared by dissolving MPC powders in distilled water, maintained 
at $40^{\circ} \mathrm{C}$. Each experiment was carried out in a $250-\mathrm{mL}$ glass beaker, equipped with an overhead stirrer 4-blade impeller (Caframo, Georgian Bluffs, Ontario, Canada) rotating at $400 \mathrm{rpm}$. The iC FBRM software (version 4.3.391, Mettler-Toledo AutoChem Inc., Columbia, $\mathrm{MD}$ ) was used to monitor and acquire the FBRM data. The software program enabled tracking of the number of particles in the category of $<10 \mu \mathrm{m}$. The dissolution characteristics of control MPC powders and powders stored at $25^{\circ} \mathrm{C}$ and $40^{\circ} \mathrm{C}$ for $1,2,4,8$, and 12 wk were monitored using changes in particle counts over time for 30 min. During the dissolution of MPC powders, the counts of fine particles $(<10 \mu \mathrm{m}$ chord length) are expected to increase with time, and hence the fine particle counts were plotted against powder dissolution time. Subsequently, the area under the fine particle count curve was extracted to characterize the powder dissolution. The area under the curve was calculated using the trapezoidal rule. Relative dissolution index (RDI, \%) was derived for the MPC powders stored for time $\mathrm{t}$ in weeks from the area under the fine particle count of the MPC powder at time $t$ and the area under the fine particle count of the same MPC powder when it was control $(t=0)$. Equation [2] was used for calculating the RDI (\%):

$$
\begin{aligned}
& \mathrm{RDI}(\%)= \\
& \frac{\text { Area under the curve for the sample at time } \mathrm{t}}{\text { Area under the curve for the sample at time } 0} \times 100 \text {. }
\end{aligned}
$$

\section{FFFS}

Front-face fluorescence spectra of all the 220 samples were collected using a Perkin-Elmer (Waltham, MA) LS50B Luminescence spectrometer equipped with the front face accessory. On each experimental day, the MPC powder sample was loaded into a powder sample holder with a quartz window. To obtain the fluorescence spectra, the powder sample holder was then mounted on a front-face accessory fitted to a PerkinElmer LS50B spectrometer, maintaining an incidence angle of excitation at $56^{\circ}$. Five scans were performed on each MPC sample to record the fluorescence emission spectra of tryptophan (305 to $450 \mathrm{~nm}$ ) at an excitation wavelength of $290 \mathrm{~nm}$, Maillard products emission spectra (380 to $480 \mathrm{~nm}$ ) at an excitation wavelength of $360 \mathrm{~nm}$, and the Maillard excitation spectra in the 260 to $350 \mathrm{~nm}$ range at an emission of $410 \mathrm{~nm}$. The slit widths were set at 9.0 and $4.0 \mathrm{~nm}$ for excitation and emission, respectively. Each MPC sample was analyzed in triplicate. Therefore, a total of 15 individual spectra were collected for each sample in the regions described above. The FL Data Manager Software (Perkin-Elmer) was used for the spectral data acquisition.

\section{Spectral Data Analysis}

The spectral data were analyzed by the technique of multivariate statistical analysis. All spectral preprocessing was accomplished in the Unscrambler $\mathrm{X}$ 10.4.1 software (CAMO Software Inc., Oslo, Norway). For the pre-processing, spectral scans from each sample at each temperature and storage time were averaged. Subsequently, fluorescence spectra were normalized by area normalization technique available in the Unscrambler X software to reduce the light scattering effects and noise. Principal component analysis (PCA) was then applied to examine the differences between MPC samples stored at various temperatures and time combinations. Principal component analysis was helpful in calculating several principal components (PC), which can give insights into the differences between the samples.

\section{Model Development and Performance Evaluation}

In this work, 220 samples were divided into a training set comprising $70 \%$ of samples for the development of partial least squares regression (PLSR) model and the remaining $30 \%$ of samples as a test set for independent validation of the model (Revilla et al., 2009). The data set was partitioned using the caret (classification and regression training) package available in $\mathrm{R}$ (The R Foundation for Statistical Computing, Vienna, Austria). The relationship between spectral measurements and solubility were obtained by applying PLSR analysis available in the Unscrambler software. The PLSR uses the 2-block predictive PLSR to model the relationship between 2 matrices, X (the input matrix) and Y (desired output matrix). The fluorescence spectra collected on the MPC powders were related to their respective solubility index and RDI using PLSR. The maximum number of latent variables was selected based on the lowest root mean square error of cross validation (RMSECV; Takahama and Dillner, 2015). The predictive ability of the model was assessed by the root mean square error of prediction (RMSEP; Equation [3]).

$$
\text { RMSEP }=\sqrt{\frac{\sum_{i=1}^{n}\left(Y_{\text {pred }}-Y_{\text {obs }}\right)^{2}}{n}},
$$

where $Y_{\text {pred }}$ is the predicted value, $Y_{o b s}$ is the observed value, and $n$ is the number of samples in the test set.

The prediction accuracy of the model was assessed using the residual prediction deviation (RPD) value, 
Table 1. Compositional analysis (\% wt/wt; means $\pm \mathrm{SD})$ of milk protein concentrate (MPC) powders used in this study

\begin{tabular}{llccrr}
\hline Type $^{1}$ & Manufacturer $^{2}$ & $\begin{array}{c}\text { Protein } \\
(\%, w t / w t)\end{array}$ & $\begin{array}{c}\text { Fat } \\
(\%, w t / w t)\end{array}$ & $\begin{array}{c}\text { Moisture } \\
(\%, w t / w t)\end{array}$ & $\begin{array}{c}\text { Lactose } \\
(\%, w t / w t)\end{array}$ \\
\hline MPC70 $(\mathrm{n}=3)$ & $\mathrm{M}_{1}, \mathrm{M}_{2}$ & $70.4 \pm 0.31$ & $1.3 \pm 0.05$ & $4.7 \pm 0.13$ & $16.1 \pm 0.48$ \\
MPC80 $(\mathrm{n}=4)$ & $\mathrm{M}_{1}, \mathrm{M}_{4}$ & $81.6 \pm 0.38$ & $1.1 \pm 0.06$ & $4.9 \pm 0.11$ & $6.6 \pm 0.55$ \\
MPC85 (n=6) & $\mathrm{M}_{1}, \mathrm{M}_{2}, \mathrm{M}_{4}$ & $85.7 \pm 0.41$ & $1.1 \pm 0.05$ & $4.9 \pm 0.11$ & $6.3 \pm 0.10$ \\
MPC90 (n=7) & $\mathrm{M}_{1}, \mathrm{M}_{2}, \mathrm{M}_{3}, \mathrm{M}_{4}$ & $88.1 \pm 0.47$ & $1.1 \pm 0.07$ & $4.6 \pm 0.14$ & $0.5 \pm 0.67$ \\
\hline
\end{tabular}

${ }^{1} \mathrm{MPC} 70,80,85$, and 90 refer to $70,80,85$, and $90 \%$ protein content, respectively.

${ }^{2}$ Samples with same subscript originate from the same manufacturer.

defined as the relationship between the standard deviation of the solubility index and RDI measurements and that of prediction in the FFFS model (Williams and Sobering, 1996). In the present study, RPD values $<1.5$ indicated a very poor model; RPD between 2 and 2.5 indicated a fair model or predictions that may be used for approximate quantitative predictions; and RPD values between 2.5 and 3.0 and $>3.0$ indicated good and very good predictions, respectively (Amamcharla and Metzger, 2015).

\section{RESULTS AND DISCUSSION}

As per the certificate of analysis provided by the manufacturer, the composition of MPC powders used in this study is shown in Table 1. As the protein content increased from 70.3 to $88.1 \%$ (wt/wt), the lactose content decreased from 16.1 to $0.5 \%$ (wt/wt). The MPC powders used in this study did not exhibit any difference in the levels of fat.

\section{Color}

The mean of $\mathrm{L}^{*}, \mathrm{a}^{*}$, and $\mathrm{b}^{*}$ were used to evaluate the changes in color before and during storage at 25 and $40^{\circ} \mathrm{C}$ (Table 2). As expected, storage at $40^{\circ} \mathrm{C}$ showed a decrease in $\mathrm{L}^{*}$ values and an increase in $\mathrm{a}^{*}$ and $\mathrm{b}^{*}$ values. Also, a similar trend was observed with the increase in protein content from 70 to $90 \%$. The decrease in the $\mathrm{L}^{*}$ value shows an increase in brown coloration and decrease in lightness in stored MPC powders. Additionally, the increase in $\mathrm{a}^{*}$ and $\mathrm{b}^{*}$ values (Table 2 ) also indicated a brown pigment formation in MPC powders. However, of the color parameters measured, the $b^{*}$ value was the most sensitive indicator of the effects of both temperature and protein content on the progress of the late-stage Maillard reaction. Le et al. (2011) found that MPC80 after storage for $12 \mathrm{wk}$ (at 25 and $40^{\circ} \mathrm{C}$ ) also developed similar changes, which they believed are the most sensitive indicators of the effects of storage temperature and time on the progress of the late-stage Maillard reaction during storage.

\section{Solubility Index}

The solubility indexes of the MPC powders after storage at 25 and $40^{\circ} \mathrm{C}$ for 12 wk are provided in Figures $1 \mathrm{~A}$ and $1 \mathrm{~B}$, respectively. The MPC powders stored at $25^{\circ} \mathrm{C}$ exhibited a higher solubility index as compared with powders stored at $40^{\circ} \mathrm{C}$. Storing the MPC powders at $40^{\circ} \mathrm{C}$ resulted in crosslinking networks at the surface of the MPC powders (Anema et al., 2006). These crosslinking networks include interactions between hydrophobic caseins and whey proteins, which hinders the hydration in the MPC powders (Anema et al., 2006; Uluko et al., 2016). As expected, the solubility of MPC has decreased with the increase in the protein content from 70 to $90 \%$ and this reduced solubility can be attributed

Table 2. The mean values of $\mathrm{L}^{*}$, $\mathrm{a}^{*}$, and $\mathrm{b}^{*}$ for the milk protein concentrate (MPC) samples received from one of the manufacturers before storage and samples stored at 25 and $40^{\circ} \mathrm{C}$ for $12 \mathrm{wk}^{1}$

\begin{tabular}{|c|c|c|c|c|c|c|c|c|c|c|}
\hline \multirow{2}{*}{$\begin{array}{l}\text { Protein } \\
\text { content }^{2}\end{array}$} & \multirow[b]{2}{*}{ Manufacturer } & \multicolumn{3}{|c|}{$\begin{array}{l}\text { Before storage } \\
\text { (control powders) }\end{array}$} & \multicolumn{3}{|c|}{$\begin{array}{l}\text { Powders stored at } \\
25^{\circ} \mathrm{C} \text { for } 12 \mathrm{wk}\end{array}$} & \multicolumn{3}{|c|}{$\begin{array}{l}\text { Powders stored at } \\
40^{\circ} \mathrm{C} \text { for } 12 \mathrm{wk}\end{array}$} \\
\hline & & $\mathrm{L}^{*}$ & $a^{*}$ & $\mathrm{~b}^{*}$ & $\mathrm{~L}^{*}$ & $a^{*}$ & $b^{*}$ & $\mathrm{~L}^{*}$ & $a^{*}$ & $b^{*}$ \\
\hline MPC70 & $\mathrm{M}_{1}$ & 93.65 & -0.95 & 10.62 & 93.32 & -0.45 & 10.97 & 91.89 & 0.05 & 17.25 \\
\hline MPC80 & $\mathrm{M}_{1}$ & 92.24 & -0.29 & 10.20 & 91.39 & -0.21 & 12.49 & 88.41 & 0.62 & 21.70 \\
\hline MPC85 & $\mathrm{M}_{1}$ & 92.24 & -0.34 & 9.67 & 91.19 & 0.08 & 12.17 & 89.09 & 0.42 & 20.73 \\
\hline МPC90 & $\mathrm{M}_{1}$ & 92.71 & -0.21 & 9.26 & 90.12 & 0.18 & 12.25 & 89.41 & 0.48 & 18.23 \\
\hline
\end{tabular}

${ }^{1} \mathrm{~L}^{*}, \mathrm{a}^{*}, \mathrm{~b}^{*}$ color system: $\mathrm{L}^{*}(0=$ black; $100=$ white component $), \mathrm{a}^{*}(+=$ red; $-=$ green component $)$, and $\mathrm{b}^{*}(+=$ yellow; $-=$ blue component).

${ }^{2} \mathrm{MPC} 70,80,85$, and 90 refer to 70, 80, 85, and $90 \%$ protein content, respectively. 

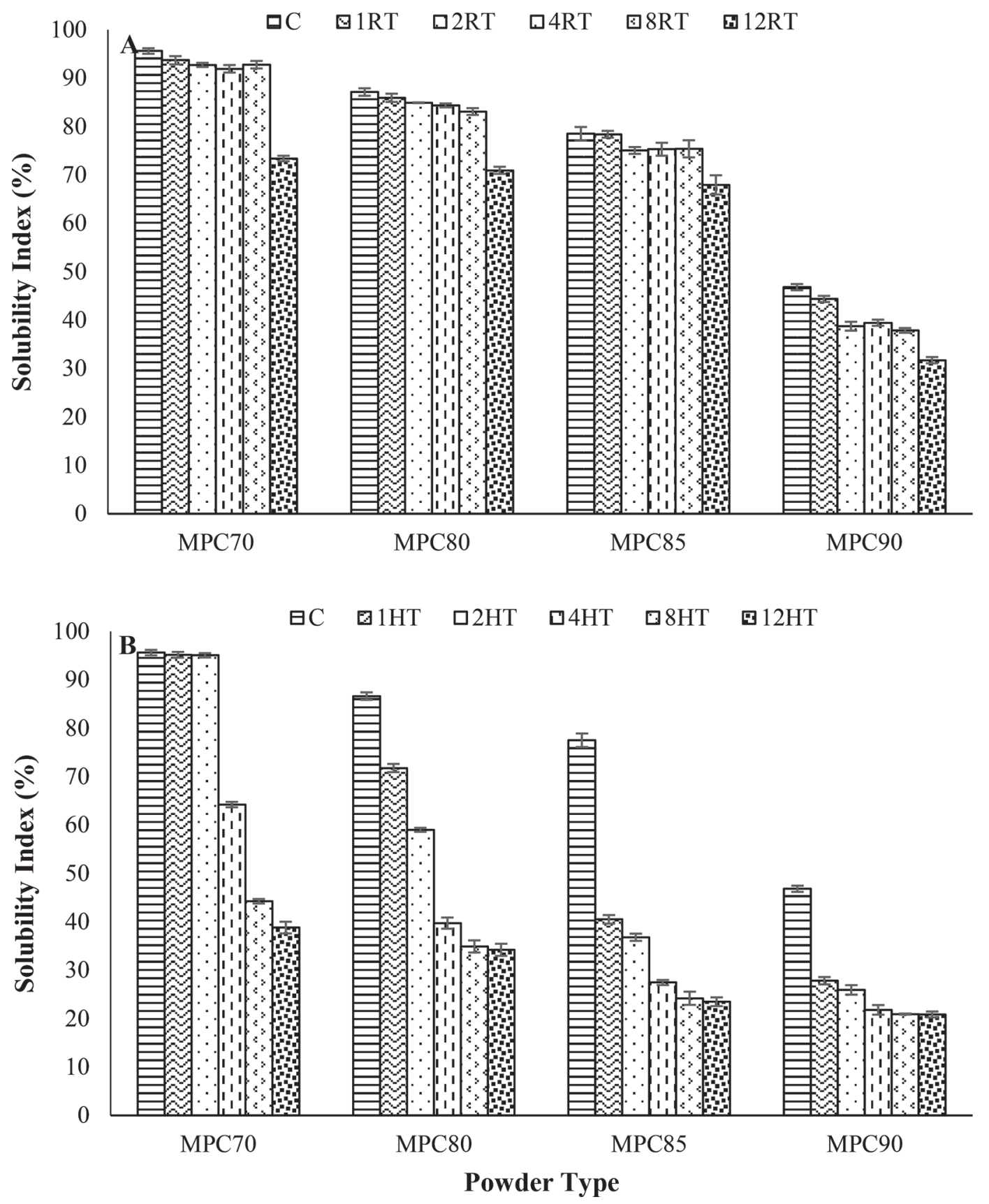

Figure 1. Solubility index (\%) of selected (from the same manufacturer) milk protein concentrate (MPC) powders with $70,80,85$, and $90 \%$ protein content before and during storage at $(\mathrm{A}) 25^{\circ} \mathrm{C}(\mathrm{RT})$ and $(\mathrm{B}) 40^{\circ} \mathrm{C}(\mathrm{HT})$ for control $(\mathrm{C}), 1,2,4,8$, and 12 wk. The numbers in the legend represent the storage time in weeks for samples collected from the same manufacturer. Error bars indicate SD.

to the reduction in lactose concentration. Lactose plays a critical role in decreasing the powder dissolution time by causing the water to enter the core of the powder particle. Previous studies reported that solubility of MPC powders is at a maximum immediately after production and decreases with the increase in storage time and temperature (Anema et al., 2006; Fyfe et al., 2011), which agreed with the results from this study.
Also, the increase in protein content negatively affected the solubility (Gazi and Huppertz, 2015).

\section{Relative Dissolution Index}

Solubility index method described above measures the status of the MPC powder at the end of the rehydration period (generally $30 \mathrm{~min}$ ) by selectively remov- 
ing the undissolved particles by centrifugation. On the other hand, FBRM-based method can provide in-line monitoring capability of powder rehydration process in a comparatively robust manner without the need for sampling or dilution. It has been proved to be a suitable technique for studying the rehydration of MPC powders (Fang et al., 2011). The FBRM results suggested that dissolution characteristics of MPC powder were influenced by the protein content and storage temperature. The RDI of the MPC powders before and after storage $(1,2,4,8$, and $12 \mathrm{wk})$ at 25 and $40^{\circ} \mathrm{C}$ is provided in Figures $2 \mathrm{~A}$ and $2 \mathrm{~B}$, respectively. The MPC powders stored at $25^{\circ} \mathrm{C}$ exhibited higher RDI as compared with powders stored at $40^{\circ} \mathrm{C}$. Interpretation of FBRM data matches the overall trend obtained from Crowley et al. (2015) and Hauser and Amamcharla (2016b). Fang et al. (2011) compared the dissolution rate constant and the final particle size for control and stored MPC. They observed that control MPC powders were the most soluble and had a high dissolution rate constant and a lower final mean particle size. A comparable approach was used to understand the dissolution behavior MPC powders in the present study. Additionally, the RDI has decreased with the increase in the protein content from 70 to $90 \%$. The changes in the fine particle counts $(<10 \mu \mathrm{m}$ chord length) of MPC70 and MPC90 from the same manufacturer (control and stored at $40^{\circ} \mathrm{C}$ for $1,2,4,8$ and 12 wk) are provided in Figures $3 \mathrm{~A}$ and $3 \mathrm{~B}$, respectively. The MPC80 and MPC85 also exhibited similar trends with increasing storage temperature and time (data not shown). It was observed that fine particle counts increased more rapidly for MPC70 stored at $40^{\circ} \mathrm{C}$ as compared with MPC90 stored at $40^{\circ} \mathrm{C}$ during dissolution. Additionally, the slow distribution rate of particles establishes the effect of storage temperature/time on the MPC powders. Similar observations were obtained in previous studies (Hauser and Amamcharla, 2016b). Storing the MPC powders at elevated temperatures such as $40^{\circ} \mathrm{C}$ resulted in crosslinking networks at the surface of the MPC powders and could be attributed to its poor dissolution characteristics (Anema et al., 2006). The crosslinking networks include interactions between hydrophobic caseins and whey proteins, and thereby hinder the hydration in the MPC powders (Anema et al., 2006; Uluko et al., 2016). As the protein content increased in MPC powders from 70 to $90 \%$ (wt/wt), the MPC90 showed more primary particle aggregates and exhibited more resistance to dispersing in water (Crowley et al., 2015). Also, with the increase in storage temperature the protein-protein aggregations increased, as shown by lesser counts of fines in FBRM. Therefore, composition and storage of MPC powders resulted in powders with diverse physical characteristics.

\section{Front-Face Fluorescence Spectra}

Tryptophan Emission Spectra. Before storage, the MPC samples with different protein contents from the same manufacturer displayed different characteristics in the individual tryptophan emission spectra, with minor variations in the peaks of the spectra for the samples stored at $25^{\circ} \mathrm{C}$ (Figure 4). Figures $4 \mathrm{~A}, 4 \mathrm{~B}, 4 \mathrm{C}$, and $4 \mathrm{D}$ show an overlaid plot of the averaged and area normalized emission spectra for tryptophan in MPC70 and MPC90 (before and during storage at 25 and $40^{\circ} \mathrm{C}$ for, $1,2,4,8$, and $12 \mathrm{wk}$ ). Before storage, the tryptophan emission spectra of MPC70 at $25^{\circ} \mathrm{C}$ (Figure 4A) exhibited a tryptophan maximum at around $341.5 \mathrm{~nm}$, whereas for MPC90 at $25^{\circ} \mathrm{C}$, the tryptophan maximum was around $341 \mathrm{~nm}$ (Figure 4B). Evident changes in the tryptophan emission spectra were observed during storage of the MPC powders, especially for the samples stored at $40^{\circ} \mathrm{C}$. The tryptophan emission peaks corresponding MPC70 and MPC90 after storage for 1, 2, 4, 8 , and 12 wk at $40^{\circ} \mathrm{C}$ presented a red shift. A decrease in peak intensity, as well as red shifts, was previously reported for the tryptophan emission spectra of NFDM powders before storage and samples stored at $50^{\circ} \mathrm{C}$ for 1, 2, 4, and $8 \mathrm{wk}$ (Liu and Metzger, 2007). On the other hand, the tryptophan emission peaks corresponding to MPC70 and MPC90 after storage for 1, 2, 4, 8, and 12 wk at $25^{\circ} \mathrm{C}$ presented a blue shift. The emission of tryptophan is highly sensitive to its local environment, and the spectral peak shifts demonstrate the protein conformational changes in the MPC powders during storage.

The MPC80 and MPC85 samples displayed similar trends during storage (data not shown). Spectral shifts in tryptophan emission observed for the MPC powders could be due to the protein-protein association and protein unfolding (Lakowicz, 2006). After 1 wk of storage, the tryptophan emission spectra of MPC70 (Figure 4A) exhibited a tryptophan maximum at around $338 \mathrm{~nm}$ at $25^{\circ} \mathrm{C}$. For $\mathrm{MPC} 70$ at $40^{\circ} \mathrm{C}$, the tryptophan maximum was around $344 \mathrm{~nm}$ (Figure 4B). Similarly, after $1 \mathrm{wk}$ of storage the tryptophan emission spectra of MPC90 at $25^{\circ} \mathrm{C}$ (Figure $4 \mathrm{C}$ ) exhibited a tryptophan maximum at around $339.5 \mathrm{~nm}$. For MPC90 at $40^{\circ} \mathrm{C}$, the tryptophan maximum was around $344.5 \mathrm{~nm}$ (Figure 4D). The prominent peak around $338 \mathrm{~nm}$ in the tryptophan emission spectra was attributed to the presence of tryptophan in NFDM (Liu and Metzger, 2007). For the tryptophan emission spectra of MPC70 and MPC90, a prominent decrease in the peak intensities between 335 and $355 \mathrm{~nm}$ was observed with the increase in storage time (Figure 4B and Figure 4D), indicating changes in the environment of the tryptophan residues in dairy proteins during storage (Liu and Metzger, 2007). 

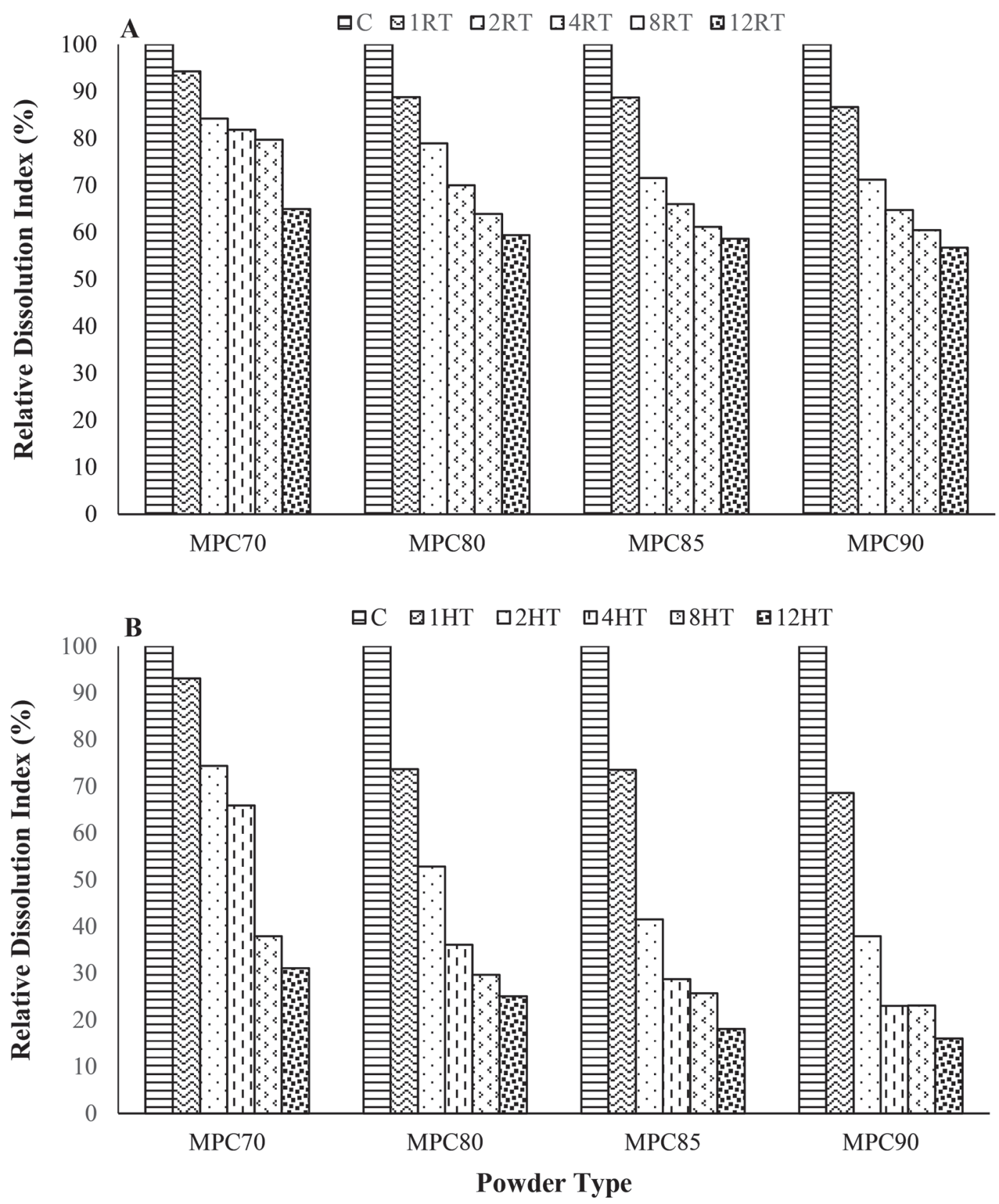

Figure 2. Relative dissolution index (\%) of selected (from the same manufacturer) milk protein concentrate (MPC) powders with 70, 80, 85, and $90 \%$ protein content before and during storage at (A) $25^{\circ} \mathrm{C}(\mathrm{RT})$ and (B) $40^{\circ} \mathrm{C}(\mathrm{HT})$ for control (C), 1, 2, 4, 8, and 12 wk. The numbers in the legend represent the storage time in weeks for samples collected from the same manufacturer.

Maillard Emission Spectra. An overlaid plot of Maillard emission spectra for MPC70 and MPC90 (before and after storage at 25 and $40^{\circ} \mathrm{C}$ for $1,2,4,8$, and 12 wk) is shown in Figure 5. The MPC80 and MPC85 samples displayed similar trends of changes during storage (data not shown). The Maillard emission spectra show a broad peak from 420 to $450 \mathrm{~nm}$ with an emission maximum $435 \mathrm{~nm}$ for MPC70 at $25^{\circ} \mathrm{C}$ (Figure $5 \mathrm{~A}$ ). For MPC70 at $40^{\circ} \mathrm{C}$, the emission maximum was found to be at $438 \mathrm{~nm}$ (Figure 5B). The emission maximum of Maillard emission spectra of MPC90 at 25 and $40^{\circ} \mathrm{C}$ was at $435 \mathrm{~nm}$ (Figure 5C) and $438 \mathrm{~nm}$ (Figure 5D), respectively. Advanced Maillard products (AMP) in milk samples have been reported (Birlouez-Aragon et al., 1998) to excite around $350 \mathrm{~nm}$ with emission at $440 \mathrm{~nm}$, which is almost identical to the peak observed in the present study. Previous studies reported that the development of Amadori products and advanced 

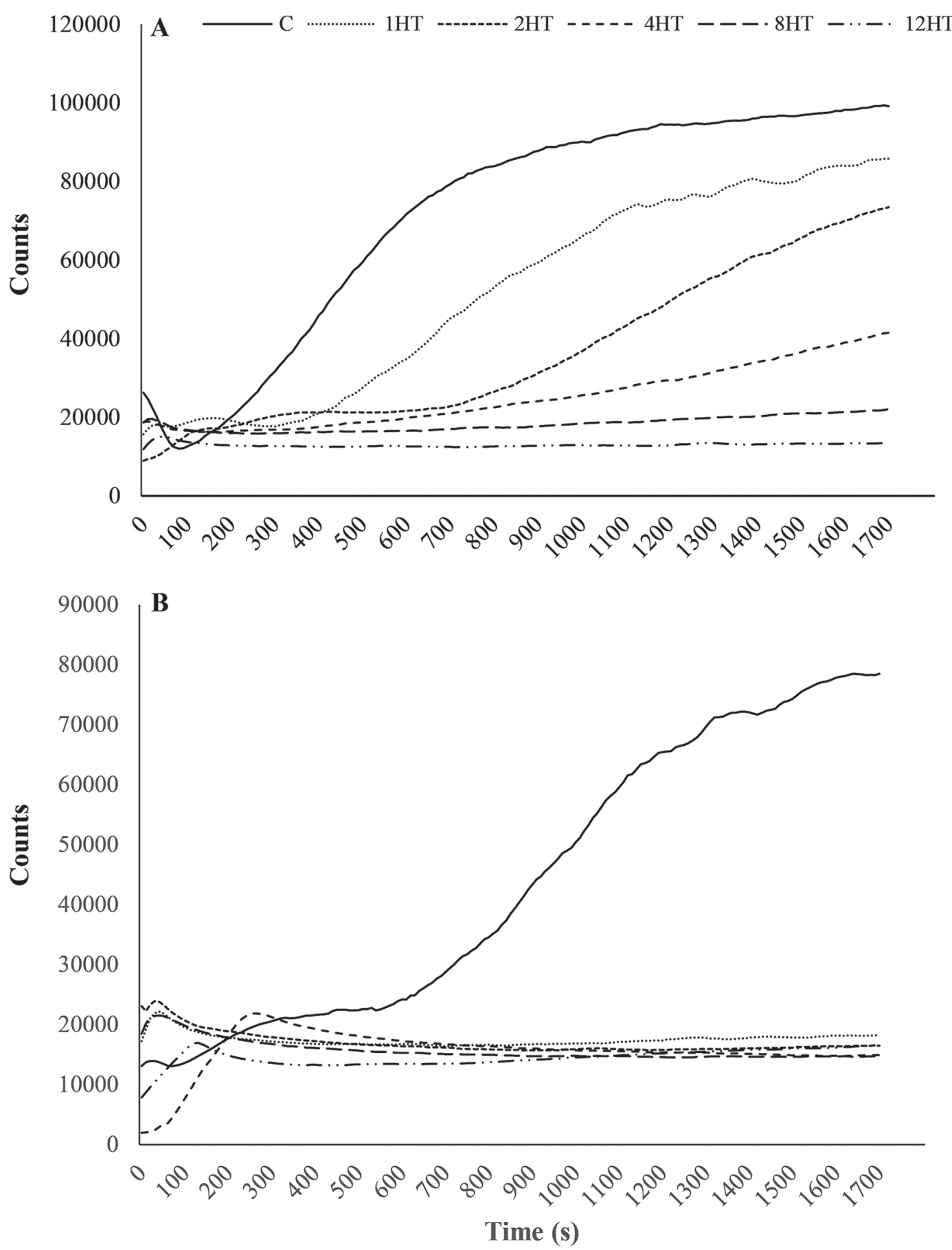

Figure 3. Changes in fine $(<10 \mu \mathrm{m})$ counts obtained from data collected with the focused beam reflectance measurement for milk protein concentrate (MPC) powders: (A) MPC with $70 \%$ protein content (MPC70) and (B) MPC with $90 \%$ protein content (MPC90) stored at $40^{\circ} \mathrm{C}$ (HT) for control (C), 1, 2, 4, 8, and $12 \mathrm{wk}$. The numbers in the legend represent the storage time in weeks for samples collected from the same manufacturer.

glycosylation end (AGE) products has an emission wavelength in the range of 420 to $450 \mathrm{~nm}$ (Matiacevich and Buera, 2006). For the Maillard emission spectra of MPC70 and MPC90, a prominent increase in the peak intensities between 420 to $450 \mathrm{~nm}$ was observed with increase in storage time (Figure $5 \mathrm{~B}$ and $5 \mathrm{D}$ ). Thus, the peaks shown in Figure 5 correspond to AMP. These variations in the Maillard emission spectra could also be explained by the $b^{*}$ values (Table 2 ). The $b^{*}$ value is a good measure of browning in milk powders because 
it shows the color change toward yellow and brown (Morales and Van Boekel, 1998). The increase in b* values became noticeable with increasing storage time and temperature, indicating changes in color caused by the Maillard reaction. Similarly, the increase in peak intensities started in all the samples from $1 \mathrm{wk}$ of storage $\left(40^{\circ} \mathrm{C}\right)$.

Maillard Excitation Spectra. Overlaid plots of Maillard excitation spectra for MPC70 and MPC90 (before and during storage at 25 and $40^{\circ} \mathrm{C}$ for $1,2,4$, 8 , and $12 \mathrm{wk}$ ) are shown in Figure 6. The MPC80 and
MPC85 samples displayed similar trends of changes during storage (data not shown). The Maillard excitation spectra for MPC70 at $25^{\circ} \mathrm{C}$ (Figure $6 \mathrm{~A}$ ), MPC70 at $40^{\circ} \mathrm{C}$ (Figure $6 \mathrm{~B}$ ), MPC90 at $25^{\circ} \mathrm{C}$ (Figure $6 \mathrm{C}$ ), and MPC90 at $40^{\circ} \mathrm{C}$ (Figure 6D) were in the range of 260 to $350 \mathrm{~nm}$ with a peak around 300 and $335 \mathrm{~nm}$. Fluorescence of Maillard products (excitation and emission wavelengths of 347 and $415 \mathrm{~nm}$ ) have been previously observed in milk systems during the Maillard reaction (Morales et al., 1996; Birlouez-Aragon et al., 2002; Liu and Metzger, 2007).
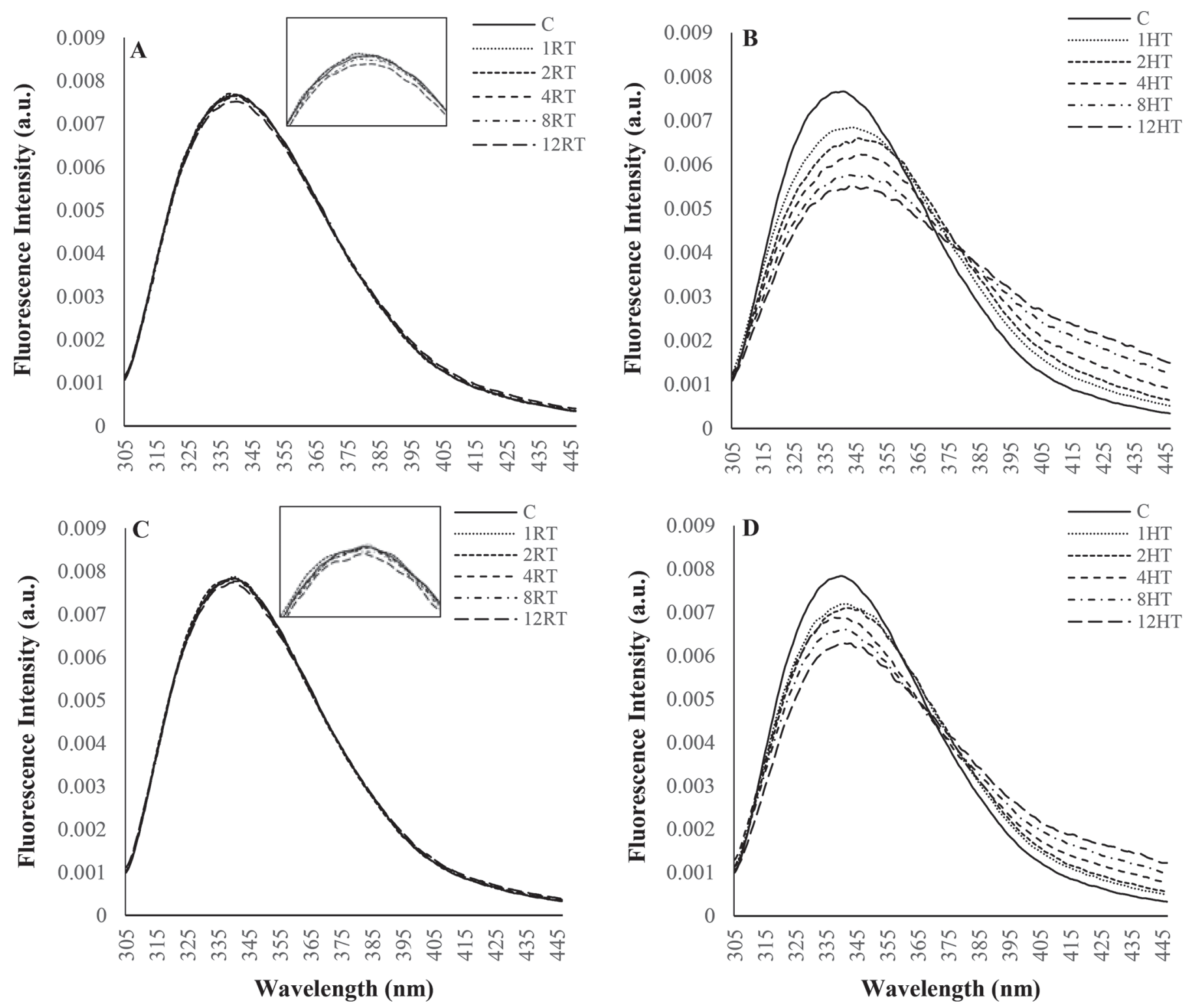

Figure 4. Averaged and normalized tryptophan emission spectra of (A, B) milk protein concentrate (MPC) with $70 \%$ protein content (MPC70) and (C, D) MPC with $90 \%$ protein content (MPC90) samples (same manufacturer) before storage and after storage at (A, C) $25^{\circ} \mathrm{C}$ $(\mathrm{RT})$ and $(\mathrm{B}, \mathrm{D}) 40^{\circ} \mathrm{C}(\mathrm{HT})$ for control (C), 1, 2, 4, 8, and $12 \mathrm{wk}$. The numbers in the legend represent the storage time of the sample in weeks. 


\section{Multivariate Analysis of MPC Fluorescence Spectra}

After storage, the PC-1 accounted for $95 \%$ of the total variability and PC-2 accounted for $4 \%$ of the total variability. The factor loadings of $\mathrm{PC}-1$ showed a positive peak at $340 \mathrm{~nm}$ and a broad negative band at around $380 \mathrm{~nm}$ (Figure 7A), and the factor loading of PC-2 exhibited a negative maximum at $335 \mathrm{~nm}$ and a positive peak at $385 \mathrm{~nm}$. The PC-1 and PC-2 described changes in the fluorescence intensity during storage and could be correlated with the changes in the normalized tryptophan spectra. In the similarity map (Figure 7D), storage at $25^{\circ} \mathrm{C}$ gave these samples larger PC- 1 scores than the samples stored at $40^{\circ} \mathrm{C}$. Discrimination of the MPC powders stored at 25 and $40^{\circ} \mathrm{C}$ was observed in the similarity maps. The tryptophan maximum emission has been previously reported in most studies in the region between 332 and $343 \mathrm{~nm}$ (Dufour et al., 2001; Kulmyrzaev et al., 2005; Ntakatsane et al., 2011), depending on the sample composition, origin, processing, and storage conditions. The changes in tryptophan maximum emission wavelength showed changes in the polarity of the tryptophan residues micro-environment (Liu et al., 2005). Therefore, variation in the hydropho-
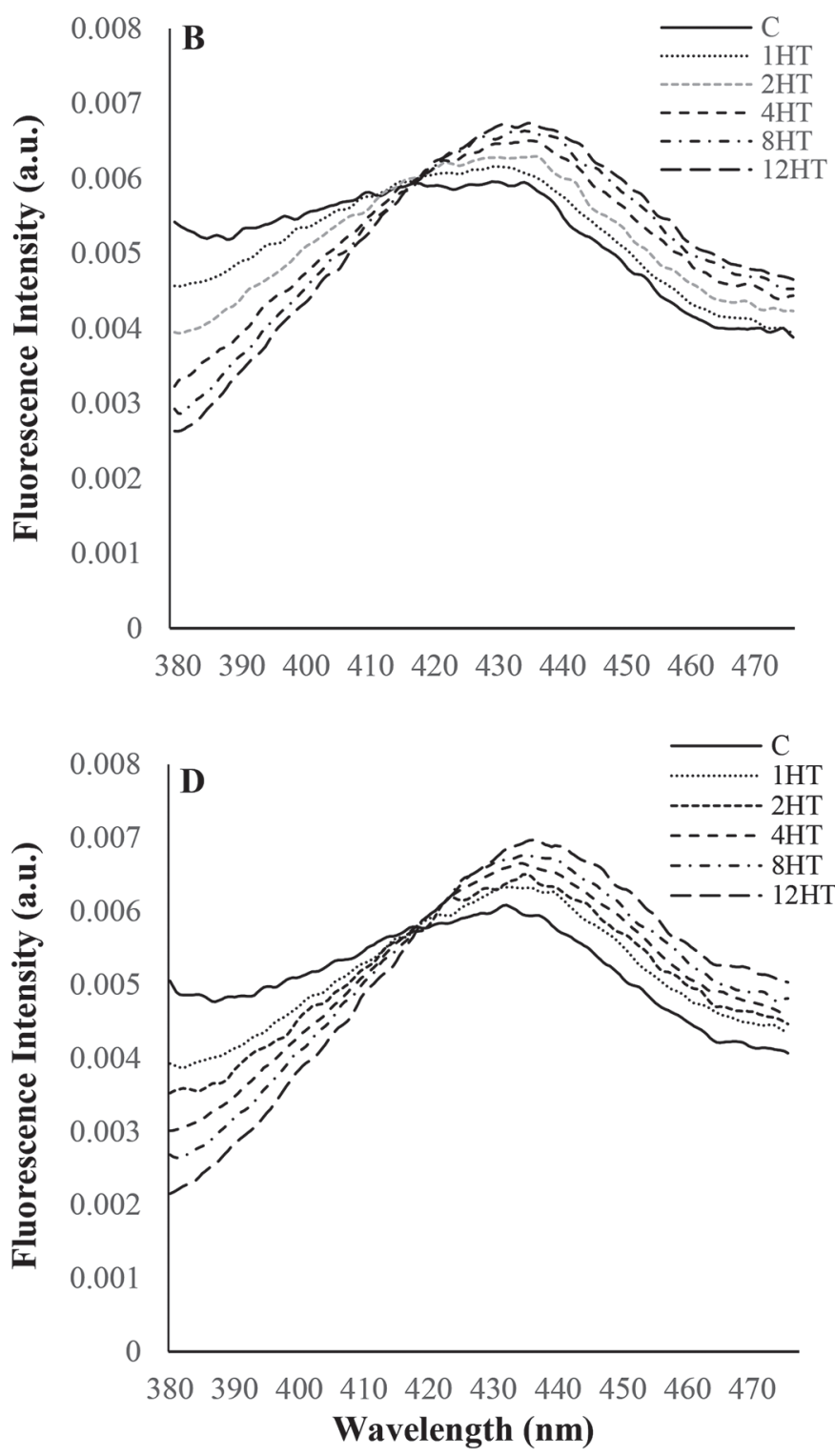

Figure 5. Averaged and normalized Maillard emission spectra of (A, B) milk protein concentrate (MPC) with 70\% protein content (MPC70) and $(\mathrm{C}, \mathrm{D}) \mathrm{MPC}$ with $90 \%$ protein content (MPC90) samples (same manufacturer) before storage and after storage at $(\mathrm{A}, \mathrm{C}) 25^{\circ} \mathrm{C}(\mathrm{RT})$ and $(\mathrm{B}$, D) $40^{\circ} \mathrm{C}(\mathrm{HT})$ for control (C), 1, 2, 4, 8, and $12 \mathrm{wk}$. The numbers in the legend represent the storage time of the sample in weeks. 

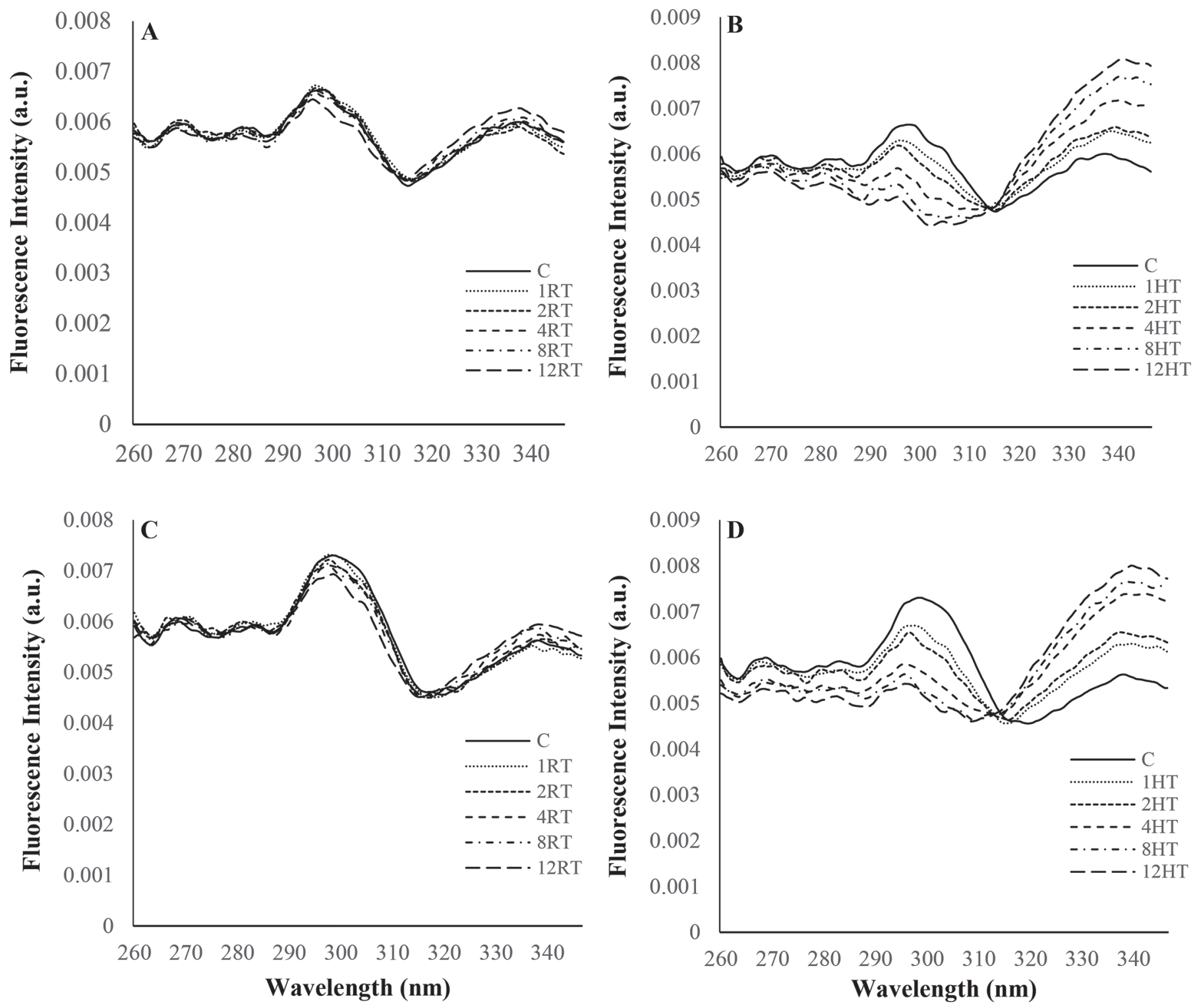

Figure 6. Averaged and normalized Maillard excitation spectra of (A, B) milk protein concentrate (MPC) with $70 \%$ protein content (MPC70) and (C, D) MPC with $90 \%$ protein content (MPC90) samples (same manufacturer) before storage and after storage at $(\mathrm{A}, \mathrm{C}) 25^{\circ} \mathrm{C}$ (RT) and (B, D) $40^{\circ} \mathrm{C}(\mathrm{HT})$ for control (C), 1, 2, 4, 8, and 12 wk. The numbers in the legend represent the storage time of the sample in weeks.

bicity of the tryptophan residues in the MPC powders after storage was found among the samples. Dufour and Riaublanc (1997) studied the FFFS tryptophan spectra of raw and heated milk and described how discriminations of the samples are a function of heat treatment. The variation in the tryptophan spectra observed in MPC powders during storage was probably due to the variation in the manufacturing conditions of the MPC powders, such as pasteurization, evaporation, spraydrying conditions, and subsequent storage conditions. Before storage, factor loading of PC-1 showed a broader negative band from 365 to $425 \mathrm{~nm}$ compared with the broader positive band from 365 to $425 \mathrm{~nm}$ of factor loading of PC-1 after storage, indicating the modification of the tryptophan environment. The variation in composition, processing, and storage conditions in the MPC samples resulted in changes in the fluorescence intensity and shifts in the emission maxima peaks to shorter wavelengths.

The factor loadings of the first $2 \mathrm{PC}$ of the Maillard emission data fluorescence data sets are presented in Figures 7B. The factor loadings plot of PC-1 showed a broad band from 425 to $440 \mathrm{~nm}$, suggesting the presence and variation of Maillard reaction products in the MPC samples, in agreement with the report by Liu and Metzger (2007) and Ntakatsane et al. (2011). They at- 
tributed positive band of $\mathrm{PC}-1$ at $430 \mathrm{~nm}$ to display the accumulation of AGE products during storage of dairy products. The factor loadings of PC-2 showed a positive band between 380 and $395 \mathrm{~nm}$ and the negative band between 385 and $440 \mathrm{~nm}$ (Figure 7B). Thus, PC-2 describes the contents of pentosidine and cross-linked compounds in the MPC samples (Liu and Metzger, 2007). Additionally, similar factors were accountable for the variation in the samples before storage (data not shown) and their changes during storage. Furthermore, Maillard emission spectra indicated that variation in the types and amounts of Maillard reaction products accumulated during their manufacturing processes depending on protein contents. The PC-1 accounted for $95 \%$ of the total variability and $\mathrm{PC}-2$ accounted for $4 \%$ of the total variability. In the PCA results of
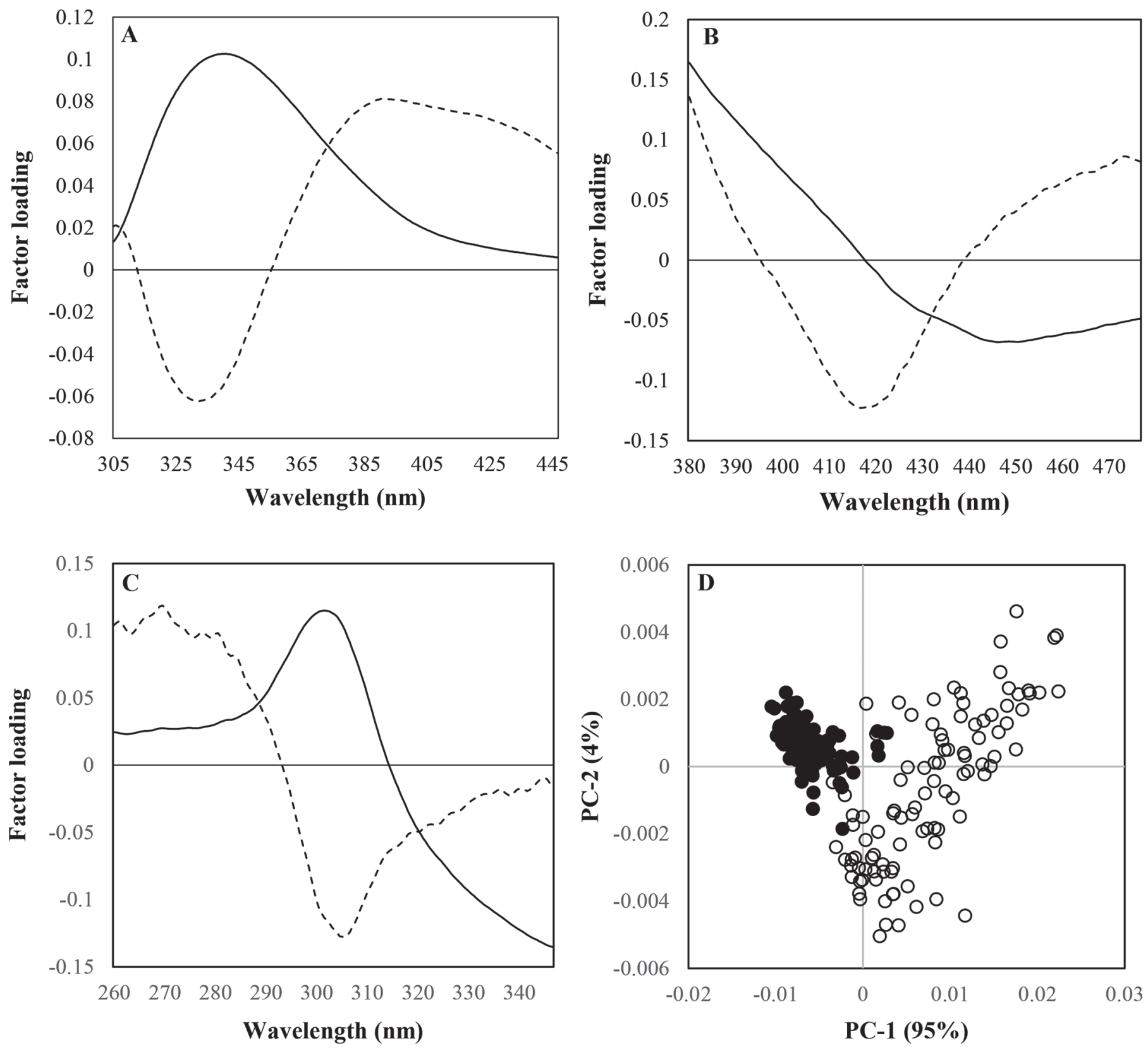

Figure 7. Factor loadings of the first 2 principal components $(\mathrm{PC})$ of principal component analysis (PCA) made on (A) tryptophan emission spectra, (B) Maillard emission spectra, and (C) Maillard excitation spectra of the milk protein concentrate (MPC) powders after storage. The solid line represents PC-1 and the dotted line represents PC-2. Similarity map (D) of PCA made on tryptophan emission spectra of the MPC powders after storage. The open circles in (panel D) represent samples stored at $25^{\circ} \mathrm{C}(\mathrm{RT})$ and the solid circles in (panel B) represent samples stored at $40^{\circ} \mathrm{C}(\mathrm{HT})$. 
Maillard emission fluorescence (data not shown), most of the MPC samples stored at $25^{\circ} \mathrm{C}$ showed positive PC-1 scores. On the other hand, most of the samples stored at $40^{\circ} \mathrm{C}$ had negative scores in PC-1. Moreaux and Birlouez-Aragon, (1997) reported maximum emission at $425 \mathrm{~nm}$, and 450 to $460 \mathrm{~nm}$ corresponds to intense Maillard reaction of $\beta-\mathrm{LG}$ and lactose, indicating AGE products. The factor loadings plot of PC-2 showed a similar negative peak at $420 \mathrm{~nm}$. Kulmyrzaev and Dufour (2002) observed a shift in the maximum emission wavelength from 416 to $419 \mathrm{~nm}$ after excessive heat treatment of the milk. Therefore, PC-1 and PC-2 may describe the presence and variation in the AGE in the MPC powders during storage. Guyomarc'h et al. (2000) reported that spray-drying conditions can influence the level of the Maillard reaction that occurs in NFDM as measured by the amount of lactosylation of milk proteins. In a previous study, Leclère and Birlouez-Aragon (2001) used a fluorescence-based method to estimate the heat treatment $\left(60^{\circ} \mathrm{C}\right)$ of milk by measuring the AMP at 330 to $420 \mathrm{~nm}$. They noted that AMP fluorescence increased during heat treatment. The solubility of the MPC powders decreased during storage, and protein cross-linking was the major reason for the solubility decrease in MPC powders during storage. In addition, the Maillard reaction also had decreased solubility during storage (Fan et al., 2018). The excitation spectra in the present study can be attributed to the presence of Maillard reaction products in the MPC samples. Previously, fluorimetric technique was used to study heat denaturation of whey proteins and the accumulation of advanced Maillard products in commercial milk samples as a function of heat treatment (Birlouez-Aragon et al., 2002). A difference was observed in the pattern of Maillard excitation data compared with that of Maillard emission data. For the Maillard excitation spectra, the characteristics of $98 \%$ of the data were described by the first 2 components.

In Figure 7C, the factor loadings of the PC-1 showed a positive peak at $300 \mathrm{~nm}$ in opposition to the negative peak at $305 \mathrm{~nm}$ in PC-2. The factor loadings of PC-1 showed a positive band between 260 and $315 \mathrm{~nm}$ and a negative band between 315 and $340 \mathrm{~nm}$. However, similar noticeable patterns were observed from the Maillard emission and excitation similarity maps (data not shown), which suggested that the Maillard emission and excitation spectra might describe the presence of similar Maillard reaction products. The factor loading of PC-2 showed a broad peak from 320 to $340 \mathrm{~nm}$, indicating changes in the intensity of the fluorescence spectra.

Overall, the factor loadings of the PC- 1 and PC-2 for the 3 fluorescence spectra of the samples before storage were comparable to the PCA results of the samples during storage. It appears that similar factors are responsible for the variation in the samples before storage and their changes during storage, which indicated that biochemical reactions such as modification of the tryptophan environment and the Maillard reaction occurred during the manufacturing process and subsequent storage of the samples. Therefore, this investigation underlines the potential of FFFS in combination with chemometrics as a fast, nondestructive method for monitoring the storage changes in MPC powders.

\section{Prediction of Solubility Index Using PLSR}

Front-face fluorescence spectra obtained on the MPC samples $(\mathrm{n}=220)$ were used to develop a PLSR model for prediction of solubility index of MPC powders. Figures $8 \mathrm{~A}, 8 \mathrm{~B}$, and $8 \mathrm{C}$ show scatter plots between the observed and predicted solubility index obtained for the entire data set. The $\mathrm{R}^{2}$, RMSECV, and RPD obtained for the data set $(n=220)$ are provided in Table 3 . The coefficient of determination $\left(\mathrm{R}^{2}\right)$ value for the 3 frontface fluorescence spectra predicted was between 0.68 and 0.84. The RMSECV for the data set was 12.99, 11.33, and 15.62 for prediction of a spectral data set of tryptophan emission, Maillard emission, and Maillard excitation, respectively. The RPD for the data set was $1.98,2.48$, and 1.75 for prediction of a spectral data set of tryptophan emission, Maillard emission, and Maillard excitation, respectively. This indicates that the developed model had good predictability and practical utility. The RPD value desired is greater than 2 for a good calibration, and a value less than 1.5 indicates incorrect predictions and an unstable model (Karoui et al., 2006; Amamcharla and Metzger, 2015). The higher correlation and more robust model for the FFFS spectral data and solubility index values support our theory that FFFS data may be used to measure the solubility index of MPC powders. The chemistry behind this correlation can be explained by the environment-sensitive characteristics of tryptophan and Maillard reaction occurred during the processing and subsequent storage.

\section{Prediction of RDI Using PLSR}

The front-face fluorescence spectra obtained on the MPC samples $(n=220)$ were used to develop a PLSR model for prediction of RDI values of MPC powders. As the FBRM measurements provide a complete overview of the rehydration process, it was predicted by using PLSR. Figures 9A and 9B show scatter plots between the observed and predicted RDI obtained for the entire data set of tryptophan and Maillard emission spectra. The $\mathrm{R}^{2}$, RMSECV, and RPD obtained for the data set $(\mathrm{n}=220)$ are provided in Table 3 . The $\mathrm{R}^{2}$ values for the 
front-face fluorescence spectra predicted were 0.58 and 0.60 for prediction of a spectral data set of tryptophan emission and Maillard emission, respectively, suggesting that the FBRM measurements (counts $<10 \mu \mathrm{m}$ )
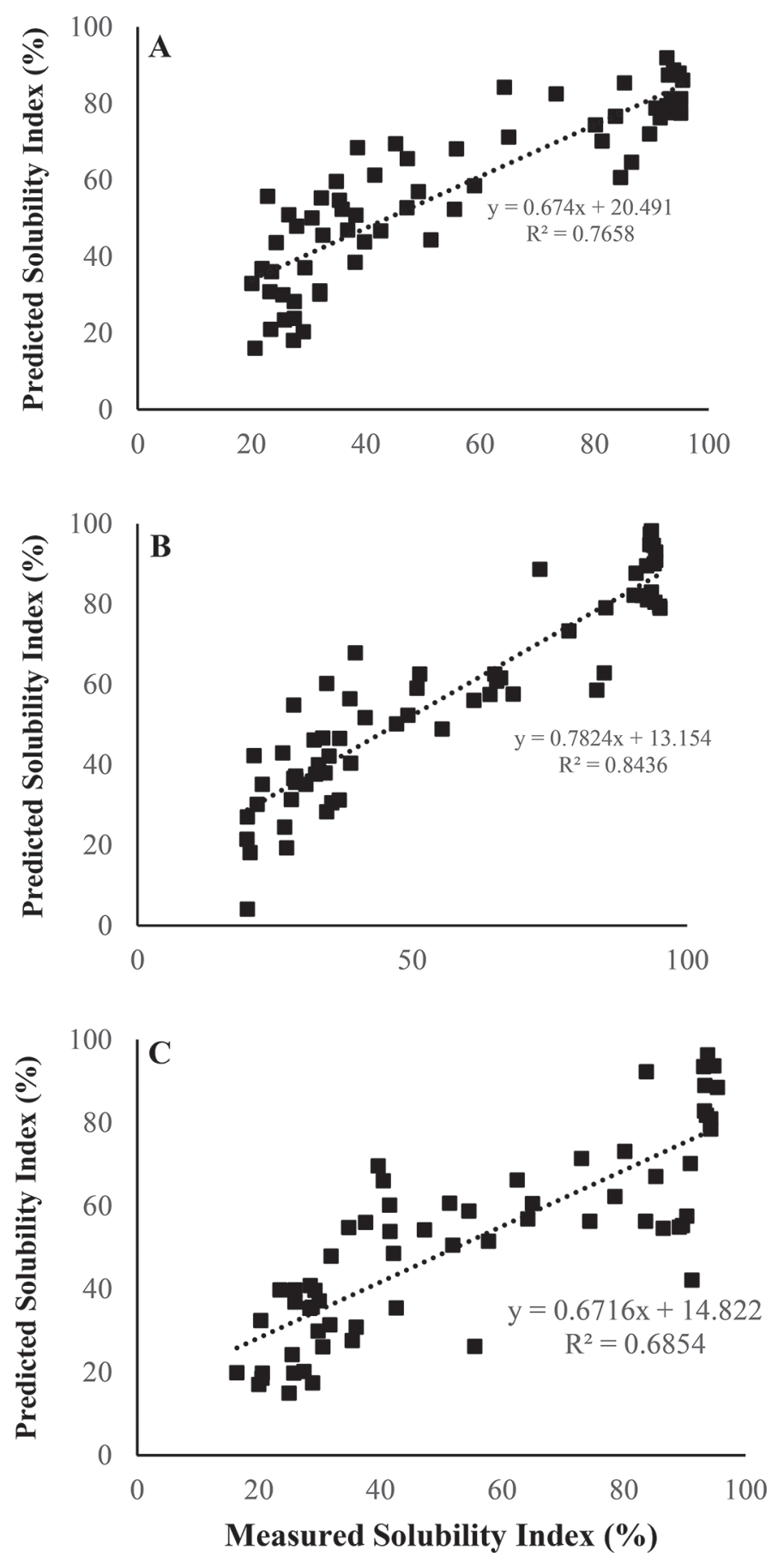

Figure 8. Model performance in test set $(\mathrm{n}=64)$ using partial least squares prediction model: measured versus predicted solubility index (\%) values plot of (A) tryptophan fluorescence spectra, (B) Maillard emission spectra, and (C) Maillard excitation spectra. could be decently predicted from the fluorescence spectra. The RMSECV for data set was 11.49 and 15.10 for prediction of a spectral data set of tryptophan emission and Maillard emission, respectively. The RPD for the data set were 1.52 and 1.53 for prediction of a spectral data set of tryptophan emission and Maillard emission, respectively. The prediction of RDI reported in the present study has suggested the feasibility of using PLSR modeling with front-face fluorescence spectral data from MPC powders. Overall, the front-face fluorescence technique provides unique information, which is a real reflection of the dissolution changes of MPC powders.
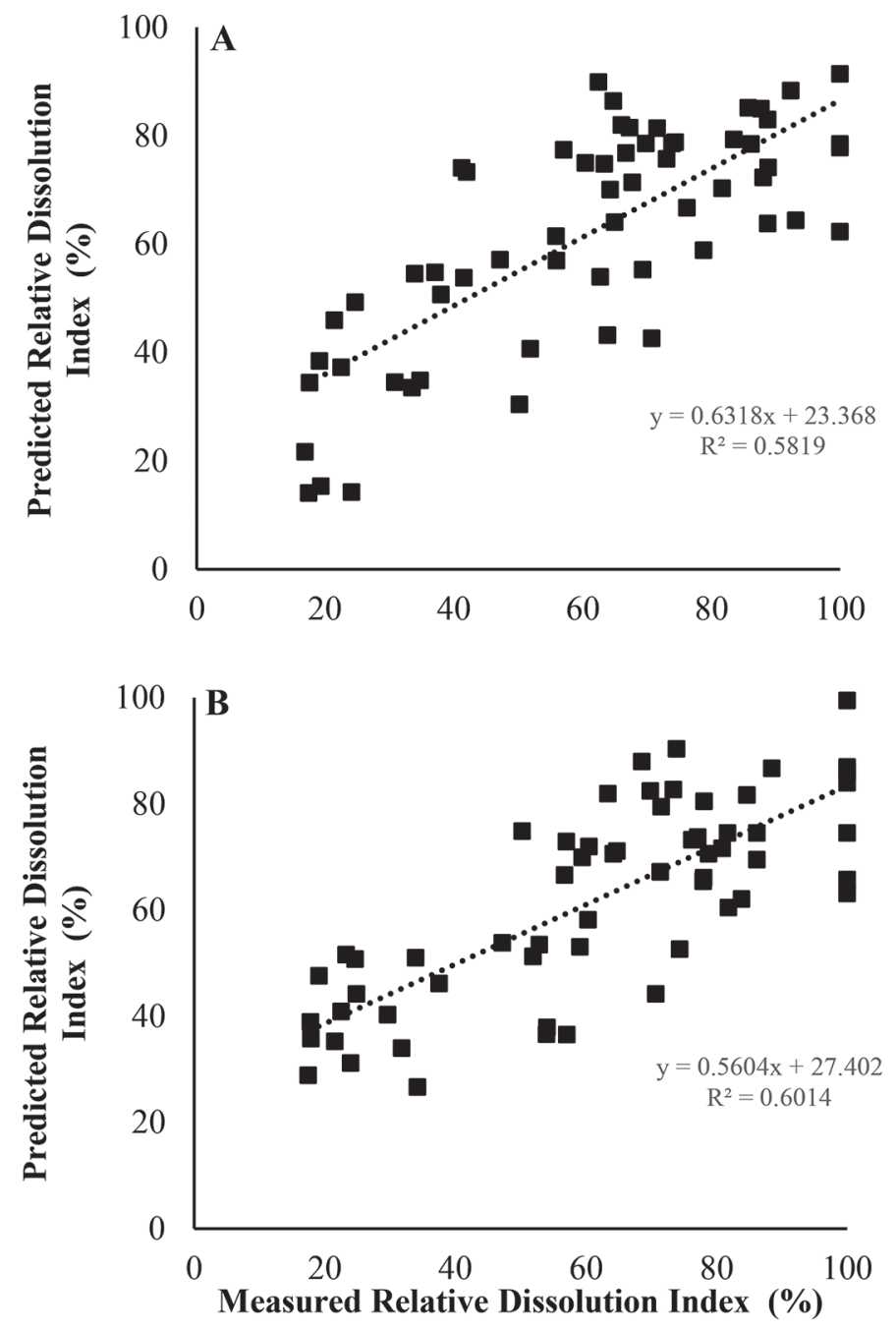

Figure 9. Model performance in test set $(\mathrm{n}=64)$ using partial least squares prediction model: measured versus predicted relative dissolution index (\%) values plot of (A) tryptophan fluorescence spectra and (B) Maillard emission spectra. 
Table 3. Summary of partial least squares predictions for solubility index and relative dissolution index using front-face fluorescence spectroscopy ${ }^{1}$

\begin{tabular}{lllr}
\hline Attribute & Spectra & Parameter & PLSR \\
\hline Solubility index & Tryptophan emission spectra & $\mathrm{R}^{2}$ & 0.76 \\
& & RMSECV & 12.99 \\
& & RMSEP & 13.94 \\
& Maillard emission spectra & RPD & 1.98 \\
& & $\mathrm{R}^{2}$ & 0.84 \\
& & RMSECV & 11.33 \\
& Maillard excitation spectra & RMSEP & 11.13 \\
& & RPD & 2.48 \\
& & R & 0.68 \\
Relative dissolution index & RMSECV & 15.62 \\
& Tryptophan emission spectra & RMSEP & 15.78 \\
& & RPD & 1.75 \\
& & R & 0.58 \\
& & RMSECV & 11.49 \\
& RMSEP & 16.03 \\
& MPD & 1.52 \\
& & R & 0.60 \\
& & RMSECV & 15.10 \\
& & RMSEP & 15.92 \\
& & RPD & 1.53 \\
\hline
\end{tabular}

${ }^{1}$ RMSECV $=$ root mean square error of cross validation; RMSEP $=$ root mean square error of prediction; RPD $=$ residual prediction deviation; PLSR $=$ partial least squares regression.

\section{CONCLUSIONS}

This study demonstrated that FFFS coupled with chemometrics has potential as a rapid technique to monitor variation in the MPC powders during storage. The FFFS combined with PLSR was successfully used as a nondestructive technique to predict the solubility and dissolution characteristics of MPC powders. The fluorescence spectra of tryptophan and Maillard products were correlated with the MPC solubility index and RDI values. This correlation may be related to changes in the environment of tryptophan and formation of Maillard products because of the changes in the MPC system due to protein content, storage time, and temperature of MPC powders. The results suggest that FFFS has the potential to provide rapid, nondestructive, and accurate measurements of solubility characteristics of MPC powders.

\section{ACKNOWLEDGMENTS}

We thank the Midwest Dairy Foods Research Center (St. Paul, MN) for their financial support. This project is Kansas State Research and Extension contribution number 18-327-J.

\section{REFERENCES}

Agarwal, S., R. L. Beausire, S. Patel, and H. Patel. 2015. Innovative uses of milk protein concentrates in product development. J. Food Sci. 80:A23-A29.

Amamcharla, J. K., and L. E. Metzger. 2015. Prediction of process cheese instrumental texture and melting characteristics using di- electric spectroscopy and chemometrics. J. Dairy Sci. 98:60046013.

Andersen, C. M., and G. Mortensen. 2008. Fluorescence spectroscopy: A rapid tool for analyzing dairy products. J. Agric. Food Chem. $56: 720-729$

Anema, S. G., D. N. Pinder, R. J. Hunter, and Y. Hemar. 2006. Effects of storage temperature on the solubility of milk protein concentrate (MPC85). Food Hydrocoll. 20:386-393.

Augustin, M. A., P. Sanguansri, R. Williams, and H. Andrews. 2012 High shear treatment of concentrates and drying conditions influence the solubility of milk protein concentrate powders. J. Dairy Res. 79:459-468.

Babu, K. S., K. Siliveru, J. K. Amamcharla, P. V. Vadlani, and R. K. Ambrose. 2018. Influence of protein content and storage temperature on the particle morphology and flowability characteristics of milk protein concentrate powders. J. Dairy Sci. 101:7013-7026.

Birlouez-Aragon, I., M. Nicolas, A. Metais, N. Marchond, J. Grenier, and D. Calvo. 1998. A rapid fluorimetric method to estimate the heat treatment of liquid milk. Int. Dairy J. 8:771-777.

Birlouez-Aragon, I., P. Sabat, and N. Gouti. 2002. A new method for discriminating milk heat treatment. Int. Dairy J. 12:59-67.

Blecker, C., J. Habib-Jiwan, and R. Karoui. 2012. Effect of heat treatment of rennet skim milk induced coagulation on the rheological properties and molecular structure determined by synchronous fluorescence spectroscopy and turbiscan. Food Chem. 135:1809-1817.

Boubellouta, T., and R. Dufour. 2008. Effects of mild heating and acidification on the molecular structure of milk components as investigated by synchronous front-face fluorescence spectroscopy coupled with parallel factor analysis. Appl. Spectrosc. 62:490-496.

Corredig, M., and D. G. Dalgleish. 1999. The mechanisms of the heatinduced interaction of whey proteins with casein micelles in milk. Int. Dairy J. 9:233-236.

Crowley, S. V., B. Desautel, I. Gazi, A. L. Kelly, T. Huppertz, and J. A. O'Mahony. 2015. Rehydration characteristics of milk protein concentrate powders. J. Food Eng. 149:105-113.

Dufour, E., M. F. Devaux, P. Fortier, and S. Herbert. 2001. Delineation of the structure of soft cheeses at the molecular level by fluorescence spectroscopy-Relationship with texture. Int. Dairy J. 11:465-473

Dufour, E., and A. Riaublanc. 1997. Potentiality of spectroscopic methods for the characterisation of dairy products. I. Front-face 
fluorescence study of raw, heated and homogenised milks. Lait $77: 657-670$.

Fan, F., M. Liu, P. Shi, X. Xu, W. Lu, Z. Wang, and M. Du. 2018. Protein cross-linking and the Maillard reaction decrease the solubility of milk protein concentrates. Food Sci. Nutr.

Fang, Y., S. Rogers, C. Selomulya, and X. D. Chen. 2012. Functionality of milk protein concentrate: Effect of spray drying temperature. Biochem. Eng. J. 62:101-105.

Fang, Y., C. Selomulya, S. Ainsworth, M. Palmer, and X. D. Chen. 2011. On quantifying the dissolution behaviour of milk protein concentrate. Food Hydrocoll. 25:503-510.

Fyfe, K. N., O. Kravchuk, T. Le, H. C. Deeth, A. V. Nguyen, and B. Bhandari. 2011. Storage induced changes to high protein powders: Influence on surface properties and solubility. J. Sci. Food Agric. 91:2566-2575.

Gazi, I., and T. Huppertz. 2015. Influence of protein content and storage conditions on the solubility of caseins and whey proteins in milk protein concentrates. Int. Dairy J. 46:22-30.

Granato, D., P. Putnik, D. B. Kovačević, J. S. Santos, V. Calado, R. S. Rocha, A. G. D. Cruz, B. Jarvis, O. Y. Rodionova, and A. Pomerantsev. 2018. Trends in chemometrics: Food authentication, microbiology, and effects of processing. Compr. Rev. Food Sci. Food Saf. 17:663-677.

Guyomarc'h, F., F. Warin, D. D. Muir, and J. Leaver. 2000. Lactosylation of milk proteins during the manufacture and storage of skim milk powders. Int. Dairy J. 10:863-872.

Hauser, M., and J. K. Amamcharla. 2016a. Development of a method to characterize high-protein dairy powders using an ultrasonic flaw detector. J. Dairy Sci. 99:1056-1064.

Hauser, M., and J. K. Amamcharla. 2016b. Novel methods to study the effect of protein content and dissolution temperature on the solubility of milk protein concentrate: Focused beam reflectance and ultrasonic flaw detector-based methods. J. Dairy Sci. 99:33343344 .

Kamal, M., and R. Karoui. 2015. Analytical methods coupled with chemometric tools for determining the authenticity and detecting the adulteration of dairy products: A review. Trends Food Sci. Technol. 46:27-48.

Karoui, R., E. Dufour, and J. De Baerdemaeker. 2007. Front face fluorescence spectroscopy coupled with chemometric tools for monitoring the oxidation of semi-hard cheeses throughout ripening. Food Chem. 101:1305-1314.

Karoui, R., and C. Blecker. 2011. Fluorescence spectroscopy measurement for quality assessment of food systems - A review. Food Bioprocess Technol. 4:364-386.

Karoui, R., E. Dufour, L. Pillonel, E. Schaller, D. Picque, T. Cattenoz, and J. Bosset. 2005. The potential of combined infrared and fluorescence spectroscopies as a method of determination of the geographic origin of emmental cheeses. Int. Dairy J. 15:287-298.

Karoui, R., G. Mazerolles, and E. Dufour. 2003. Spectroscopic techniques coupled with chemometric tools for structure and texture determinations in dairy products. Int. Dairy J. 13:607-620.

Karoui, R., A. Mouazen, E. Dufour, R. Schoonheydt, and J. Baerdemaeker. 2006. A comparison and joint use of VIS-NIR and MIR spectroscopic methods for the determination of some chemical parameters in soft cheeses at external and central zones: A preliminary study. Eur. Food Res. Technol. 223:363-371.

Kulmyrzaev, A., and E. Dufour. 2002. Determination of lactulose and furosine in milk using front-face fluorescence spectroscopy. Lait 82:725-735.
Kulmyrzaev, A. A., D. Levieux, and R. Dufour. 2005. Front-face fluorescence spectroscopy allows the characterization of mild heat treatments applied to milk. relations with the denaturation of milk proteins. J. Agric. Food Chem. 53:502-507.

Lakowicz, J. R. 2006. Principles of Fluorescence Spectroscopy. 3rd ed. Springer, New York, NY.

Le, T. T., B. Bhandari, and H. C. Deeth. 2011. Chemical and physical changes in milk protein concentrate (MPC80) powder during storage. J. Agric. Food Chem. 59:5465-5473.

Leclère, J., and I. Birlouez-Aragon. 2001. The fluorescence of advanced Maillard products is a good indicator of lysine damage during the Maillard reaction. J. Agric. Food Chem. 49:4682-4687.

Liu, X., and L. E. Metzger. 2007. Application of fluorescence spectroscopy for monitoring changes in nonfat dry milk during storage. J. Dairy Sci. 90:24-37.

Liu, X., J. R. Powers, B. G. Swanson, H. H. Hill, and S. Clark. 2005. Modification of whey protein concentrate hydrophobicity by high hydrostatic pressure. Innov. Food Sci. Emerg. Technol. 6:310-317.

Matiacevich, S. B., and M. P. Buera. 2006. A critical evaluation of fluorescence as a potential marker for the Maillard reaction. Food Chem. 95:423-430.

Mimouni, A., H. C. Deeth, A. K. Whittaker, M. J. Gidley, and B. R. Bhandari. 2010. Investigation of the microstructure of milk protein concentrate powders during rehydration: Alterations during storage. J. Dairy Sci. 93:463-472.

Morales, F. J., C. Romero, and S. Jime'nez-Pe'rez. 1996. Fluorescence associated with Maillard reaction in milk and milk-resembling systems. Food Chem. 57:423-428.

Morales, F. J., and M. Van Boekel. 1998. A study on advanced Maillard reaction in heated casein/sugar solutions: Colour formation. Int. Dairy J. 8:907-915.

Moreaux, V., and I. Birlouez-Aragon. 1997. Degradation of tryptophan in heated $\beta$-lactoglobulin-lactose mixtures is associated with intense Maillard reaction. J. Agric. Food Chem. 45:1905-1910.

Ntakatsane, M. P., X. Q. Yang, M. Lin, X. M. Liu, and P. Zhou. 2011. Suitability of fluorescence spectroscopy for characterization of commercial milk of different composition and origin. J. Dairy Sci. 94:5375-5380.

Revilla, I., I. González-Martín, J. M. Hernández-Hierro, A. VivarQuintana, C. González-Pérez, and M. A. Lurueña-Martínez. 2009. Texture evaluation in cheeses by NIRS technology employing a fibre-optic probe. J. Food Eng. 92:24-28.

Richard, B., M. Toubal, J. Le Page, G. Nassar, E. Radziszewski, B. Nongaillard, P. Debreyne, P. Schuck, R. Jeantet, and G. Delaplace. 2012. Ultrasound tests in a stirred vessel to evaluate the reconstitution ability of dairy powders. Innov. Food Sci. Emerg. Technol. $16: 233-242$.

Shaikh, S., and C. O'Donnell. 2017. Applications of fluorescence spectroscopy in dairy processing: A review. Curr. Opin. Food Sci. $17: 16-24$.

Takahama, S., and A. M. Dillner. 2015. Model selection for partial least squares calibration and implications for analysis of atmospheric organic aerosol samples with mid-infrared spectroscopy. J. Chem. 29:659-668.

Uluko, H., L. Liu, J. Lv, and S. Zhang. 2016. Functional characteristics of milk protein concentrates and their modification. Crit. Rev. Food Sci. Nutr. 56:1193-1208.

Williams, P. C., and D. C. Sobering. 1996. How do we do it: A brief summary of the methods we use in developing near infrared calibrations. Near Infrared Spectroscopy: The Future Waves. 185-188. 